J. Dairy Sci. 97:3173-3189

http://dx.doi.org/10.3168/jds.2013-7516

(C) American Dairy Science Association ${ }^{\circledR}, 2014$.

\title{
Prediction of liveweight of cows from type traits and its relationship with production and fitness traits
}

\author{
M. Haile-Mariam, ${ }^{*} \dagger^{1}$ O. Gonzalez-Recio, ${ }^{\star} \dagger$ and J. E. Pryce ${ }^{*} \dagger$ \\ *Biosciences Research Division, Department of Environment and Primary Industries, Agribio, 5 Ring Road, La Trobe University, Bundoora, \\ VIC 3083, Australia \\ †Dairy Futures Cooperative Research Centre, 5 Ring Road, La Trobe University, Bundoora VIC 3083, Australia
}

\section{ABSTRACT}

Liveweight (LWT) data for Australian Holstein cows was predicted from different type traits based on actual LWT and type data of 932 cows collected from 20 different herds over a 3 -yr period. In addition to LWT measured using scales, visual estimates of LWT were also available on $90 \%$ of the cows with LWT data. The future predictive ability of different models was assessed using 10-fold cross-validation. The relationships between LWT and selected type traits, including body condition score (BCS), were also calculated to assess the usefulness of various traits to predict LWT genetically. The relationships of predicted LWT measures with production and fitness traits were also estimated in an attempt to assess the consequence of continuous selection on an economic index that includes predicted LWT with a negative economic value. The heritability of LWT was 0.4. Among type traits, stature, chest width, bone quality, BCS, udder depth, central ligament, and muzzle width were correlated with LWT both genetically and phenotypically and were used to predict LWT of cows. Predicted LWT measures, using several sets of traits and visually estimated LWT were genetically highly correlated with each other $(>0.73)$. Phenotypically, visually estimated LWT of cows was slightly more correlated with actual LWT than that predicted from type traits, but genetically both approaches gave the same accuracy. The predicted estimates of LWT were also positively genetically correlated with energycorrected milk yield and had near zero correlation with survival. The correlations of different measures of LWT with fertility traits were unfavorable or near zero, suggesting that selection for reduced LWT may not cause deterioration in fertility traits. However, it may be useful to consider broadening the breeding objective to include traits that are associated with energy balance, particularly if traits such as BCS and bone quality are

Received September 23, 2013.

Accepted January 20, 2014.

${ }^{1}$ Corresponding author: Mekonnen.HaileMariam@depi.vic.gov.au included in the set of traits used to predict LWT. Based on the results from this study, the inclusion of predicted LWT with negative economic values into the breeding objective would have no negative effect on fitness traits. Key words: liveweight, type traits, fitness, production, genetic correlation

\section{INTRODUCTION}

Selection for increased milk production in most countries favors large cows that produce and eat more than smaller cows (Visscher et al., 1994; VanRaden, 2004) because the same maintenance feed cost is assumed for all cows of the same breed and age in some herd models used to determine economic values. Some exceptions can be found in the economic selection index in New Zealand (Harris et al., 2007), which includes liveweight (LWT) or measures of body or frame size in Australia (Valentine et al., 2000) and the United States (VanRaden, 2004). Both in Australia and the United States, the use of some measure of body size instead of LWT is justified due to the lack of LWT data and because measures of skeletal, or frame size, such as stature and heart girth, are more associated with differences in maintenance cost of LWT rather than LWT itself (Hoffman et al., 1996). Furthermore, selection for reduced LWT that includes BCS may actually increase health and fertility disorders because of the association between BCS and energy balance (Coffey et al., 2003). Veerkamp (1998) suggested that dairy cows, particularly at the beginning of lactation, mobilize body tissue and are in negative energy balance because the increase in feed intake does not cover the extra requirements for milk yield. So, selection for reduced LWT may exacerbate the extent of negative energy balance and, thus, health and fertility problems. Possibly for this reason, economic indices in some countries include LWT EBV with positive economic values (VanRaden, 2004), perhaps to increase energy intake and also improve energy balance. A recent study by Frigo et al. (2010) showed that heavier cows experience less ketosis, metabolic, infectious, and other diseases than lighter cows. 
However, in contrast, Hansen et al. (1999) observed that the herd life and fertility of small-sized Holstein cows was actually better than large cows in the United States. Selection for increased milk yield traits without the concomitant increase in LWT has been part of the New Zealand dairy cattle breeding objective since 1996, where the negative economic value of LWT is relatively high compared with other countries because of the high reliance on pasture in New Zealand production systems (Harris et al., 2007). In Australia, since 2004, EBV for predicted LWT have been included in the national breeding objective, the Australian Profit Ranking (APR), with a negative economic value. Recent analyses of the Australian data show a small downward genetic trend in chest width and BCS, possibly as a result of selection on APR (Haile-Mariam et al., 2013).

There is a renewed interest in improving efficiency of feed utilization as a means to increase profitability (Grainger and Goddard, 2004) and address the environmental impact of dairy production (de Haas et al., 2011). Optimizing the relationship between LWT and maintenance feed costs is one approach that can contribute to overall savings on feed costs. In Australian dairy cattle, the proportion of feed energy requirement for maintenance is about 50 and $25 \%$ of the total during the growth and lactation period, respectively (Bell et al., 2013). In these circumstances, it will be useful to test if continued selection for milk yield traits with constraint (i.e., less increase in LWT relative to the increase in milk yield traits) on LWT could have a negative consequence on fitness traits. The LWT of cows is a function of body size and BCS, so defining maintenance requirements as a variable that is less related to BCS may have fewer negative effects on fitness traits (Collard et al., 2000). This can be tested by predicting LWT considering all the available type traits (including those highly correlated with BCS) as well as type traits that only predict frame size, such as stature, and assessing the effect of selection for reduced LWT or frame size on fertility and health traits.

In Australia, as in many other countries, LWT data are not recorded and, thus, it is predicted from type traits. Currently, stature, chest width, and body depth are used to predict LWT (Valentine et al., 2000), although their accuracy and relevance in the current cow populations has not been investigated. Furthermore, in Australia because insufficient data are collected on fitness traits, survival from the current to the next lactation is used as a proxy for health traits. Similarly, calving interval (ClvI), lactation length (LL), calving to first service interval (CFS), and pregnancy rate (PR) are used as proxies for fertility. Other traits, such as fat-toprotein ratio (de Vries and Veerkamp, 2000; Negussie et al., 2013) can be used as an indicator of negative energy balance. This may be particularly useful to test if small-sized cows that produce relatively more milk yield with limited capacity to consume adequate feed are more prone to larger (unfavorable) ratios compared with larger cows.

The aim of this study was to assess the relationship of type traits related to body size, including predicted LWT with milk production and fitness traits in Australian Holstein dairy cattle. The specific objectives of this study were to (1) identify type traits that are correlated with LWT and estimate their relationship with performance traits, including milk yield, fertility, and survival; (2) predict LWT of cows from type traits and estimate the correlations of these predicted LWT measures with milk production, fertility, and survival traits in Australian Holstein dairy cattle; and (3) estimate the phenotypic and genetic trend in predicted LWT.

\section{MATERIALS AND METHODS}

\section{Data}

In Australian Holstein dairy cattle, all type traits are scored on a scale of 1 to 9 , except overall type, which is scored on a scale of 1 to 15 . Body condition score is recorded on a scale of 1 (thin) to 8 (fat) according to Earle (1979). All classifications are carried out by Holstein Australia (HA, Hawthorn BC, VIC, Australia) classifiers once during the first lactation. Although type data of cows that calved between 1994 and 2012 were used for this study, BCS data were available for cows that were type scored between 1999 and 2012. In total, about 430,000 cows, of which $45 \%$ had valid BCS data, were included. The $98 \%$ of type classifications were carried out by 33 classifiers, whereas 28 classifiers with less than 100 cows each accounted for the remaining $2 \%$ of the classifications. Type classification data of these 28 classifiers were excluded from the analyses. Days in milk at classification ranged from 1 to $500 \mathrm{~d}$, but for most analyses reported in this study, classification after $365 \mathrm{~d}$ were set to missing. Data editing on age at classification and age at calving also removed cows classified after 49 mo of age or cows that first calved after 38 mo of age.

To achieve the objectives of the current study different data sets were used. First, type and LWT records of cows from 20 Holstein herds were used for calibrating the phenotypic prediction of LWT. Liveweights on 932 first-parity cows were recorded at the time of type classifications by HA between 2009 and 2011. Close to $90 \%$ of the cows were also visually assessed and their LWT estimated by the HA classifiers immediately before they were weighed, using standard portable weigh scales. Second, to obtain improved estimates of genetic 
Table 1. Number of cows, definition, means, and SD of traits associated with liveweight (LWT) in the 2 data sets (i.e., LWT with type and type data only)

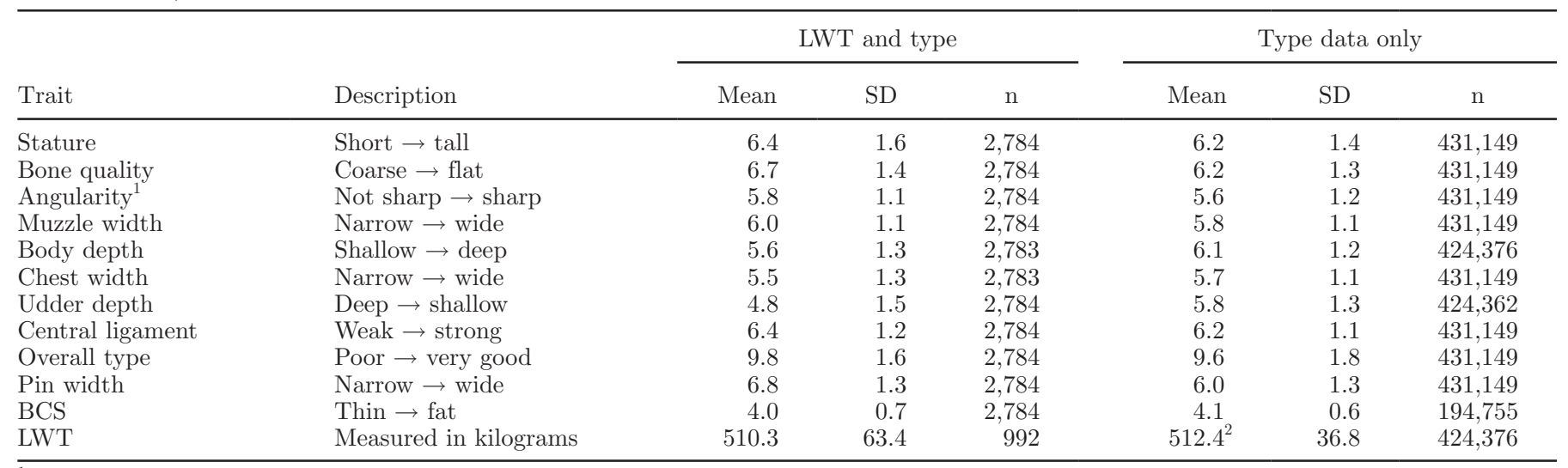

${ }^{1}$ The definition of this trait was changed in 2007.

${ }^{2}$ Predicted LWT based on the best type model.

and residual correlation of LWT with type traits, type data of cows that were contemporaries (i.e., produced in the same herd-year-season of calving) of the cows with LWT data were added to the first data set (see Table 1). Third, to calculate predicted LWT from type traits, a data set of first-parity cows that were scored between 1993 and 2012 for type traits only by HA was used. The mean, standard deviation, and description for some type traits and LWT are given in Table 1. These data were merged with production, fertility, and survival to form a fourth data set (see below for details). Except for the LWT, all the other data were extracted from the Australian Dairy Herd Improvement Scheme (ADHIS) database (http://www.adhis.com.au).

To assess the relationship between type traits, including predicted LWT and other economic dairy traits, the type data of cows were merged with milk yield, fertility, and survival data (see Table 2). About 55\% of cows with type data were identified to have records for other traits. In the merged data, survival from first to second lactation (Table 2) was slightly higher (87\%) than in the Australian Holstein average (83\%), possibly showing that some cows culled early in lactation were not classified. To ensure that the exclusion of data of cows not type classified has minimal effect on the genetic correlations between type traits (including the predicted LWT) and other traits, data of other cows were added if they were progeny of sires with type data and if they were contemporaries (i.e., in the same herdyear-season-age group) to type scored cows with their type data coded missing.

\section{Statistical Analyses}

Phenotypic Prediction of $L W T$. Different models were used to predict LWT using type traits.

(1) Best type model. Phenotypic prediction was done by fitting a multiple-regression model where all type traits were included simultaneously and type traits with no, or least significant effect, were sequentially excluded from the model. This procedure was used to identify type traits that best predicted LWT and only traits with significant $(P<0.05)$ effect were retained in the final model and used to predict LWT.

(2) Best type model plus BCS. Body condition score was added to the traits selected in the previous model.

Table 2. Number of cows with data for different fertility traits, milk, and survival and their average performance in lactations 1 and 2

\begin{tabular}{|c|c|c|c|c|}
\hline \multirow[b]{2}{*}{ Trait } & \multicolumn{2}{|c|}{ Lactation 1} & \multicolumn{2}{|c|}{ Lactation 2} \\
\hline & $\mathrm{n}$ & Mean (SD) & $\mathrm{n}$ & Mean (SD) \\
\hline ECM yield, $\mathrm{kg}$ & 473,723 & $5,989(1,978)$ & 341,813 & $6,886(2,504)$ \\
\hline Calving interval (ClvI), $\mathrm{d}$ & 359,414 & $404(63)$ & 243,728 & $402(67)$ \\
\hline Survival (Surv), \% & 447,712 & $86(35)$ & 312,361 & $83(38)$ \\
\hline Pregnancy rate (PR), \% & 63,575 & $84(37)$ & 38,592 & $82(38)$ \\
\hline Lactation length (LL), d & 483,164 & $313(81)$ & 344,564 & $303(90)$ \\
\hline Calving to first service (CFS), d & 116,398 & $87(32)$ & 75,578 & $79(34)$ \\
\hline
\end{tabular}


(3) United Kingdom (UK) model. This model includes the prediction of LWT derived for UK Holstein cows and included stature, body depth, chest width, and angularity (Banos and Coffey, 2012).

(4) Spanish model. This model includes stature as the only trait for predicting LWT, as described by Pérez-Cabal et al. (2006) in Spanish Holstein cattle.

(5) ADHIS model. The predictive model for LWT currently implemented by ADHIS was used as a benchmark. This model includes stature, body depth, and chest width.

In all cases, the values used for prediction of LWT from type traits were calculated using the current type and LWT data. In preliminary analyses, DIM and age at classification had significant effects on LWT but were not fitted in the model, as the objective of this study was to get a predicted LWT measure for cows that could be analyzed using the model applied to other type traits. In Australia, both DIM and age at classification are included as fixed effects in the genetic evaluation model for type traits, jointly with herdclassifier-round (i.e., cows from the same herd classified on the same date by the same classifier). The quality of predictions was assessed by calculating the reduction in residual variance after adding the type traits relative to the model that only included the mean. In addition, as the purpose of these models was to predict (the yet to be observed) LWT in the population from type traits, a 10-fold cross-validation was used to determine the predictive ability of each model. About 820 cows were used in each reference set (i.e., for estimating the coefficient of the equation) and 92 cows were used in each validation set (i.e., for determining the predictive ability by means of the correlation between predicted LWT and actual LWT and the root mean square error).

Finally, in each scenario (i.e., best type, ADHIS, UK, stature, best type plus BCS), predicted LWT for each cow was calculated using the estimated regression coefficient for each type trait and the intercept from the regression equations obtained from cows with LWT and type (i.e., 932 cows). Predicted LWT measures from the above models were also compared with the visually estimated LWT to test if this could improve the accuracy of genetic evaluation for LWT.

Relationship of Actual LWT with Type Traits. Genetic correlations between LWT, BCS, and the type traits that could be predictors of LWT were estimated using data from 20 herds that had recorded LWT and type data. These analyses were carried out using a multiple-trait animal model with the numerator rela- tionship matrix as a covariance structure for the random additive genetic effect and herd-classifier-round as a fixed effect. In addition, the model included age and DIM at classification as covariates and month of calving as fixed effects.

Relationship Among Predicted LWT Measures. To examine the relationship between predicted LWT measures, genetic and residual correlations among them were estimated using a multiple-trait sire model. All analyses to estimate genetic variance-covariance, described hereafter, used a sire instead of an animal model because it was thought that more reliable genetic correlations would be obtained by using a relatively large representative data set. In addition, the computer time required for analyzing a large representative data set using an animal model was expected to be a lot longer than using a sire model. In the model used to estimate genetic and residual correlations among predicted LWT measures, sires were fitted as random effects and herd-classifier-rounds were fitted as fixed effects. In addition, the model included age and DIM at classification as a covariate and month of calving as fixed effect. This was actually a 4-trait analysis of predicted LWT measures because both the genetic and residual correlation estimates of LWT predicted using the ADHIS model and the UK model were effectively 1. After the 4-trait analysis converged, data of cows with actual and visually estimated LWT were added and a 6 -trait model was rerun until convergence. This was done to find out how the various measures of LWT predicted in this study, including the visually assessed LWT, are genetically correlated with actual LWT.

To obtain genetic trends for the 4 predicted LWT measures, EBV were calculated using an animal model, because accounting for all relationships was assumed to be better to produce more reliable EBV compared with sire models. For this analysis, variance-covariance estimates from the sire model above were assumed to be true. Then genetic trends for the different predicted LWT measures by year of birth were examined by including only EBV of sires with progeny and cows with predicted LWT.

Relationship of Type Traits or Predicted LWT with Production and Fitness Traits. To better understand the relationship between predicted LWT and fitness traits, genetic and residual correlation estimates between type traits related to predicted LWT with ECM yield and fitness traits were estimated. The relationship between the type traits and fitness traits was also estimated after adjusting the type traits for differences in ECM yield of cows. Energy-corrected milk yield was calculated following Sjaunja et al. (1991) as $\mathrm{ECM}$ yield $=0.25 \times \mathrm{kg}$ of milk $+12.2 \times \mathrm{kg}$ of fat + 
$7.7 \times \mathrm{kg}$ of protein. The adjustment for ECM yield was done by fitting ECM yield as a covariate (both linear and quadratic) in the model in addition to other effects.

Relationship of Predicted LWT (Selected Type Traits) with Production and Fitness Traits in the Second Lactation. For cows that had second lactation production and fitness data, genetic and residual correlations of selected type traits and predicted LWT with production and fitness were also estimated. The type traits selected for the analyses with secondlactation data were 4 type traits (i.e., angularity, body depth, overall type, and udder depth) that were found to have a strong correlation with fitness and production traits in the first lactation.

Relationship of Predicted LWT with Fat-toProtein Ratio (as Indictor of Metabolic Stress). To examine if predicted LWT of cows is related to the ratio of fat to protein yield $(\mathbf{F} / \mathbf{P})$ we estimated genetic and residual correlations using the first-parity data. This was also done before and after adjusting the trait of interest (e.g., predicted LWT) for ECM yield. For comparison, the correlation of $\mathrm{F} / \mathrm{P}$ with $\mathrm{BCS}$ and angularity was also estimated, because BCS is considered as an indicator of robustness, and angularity as an indicator of possible metabolic stress (e.g., Miglior et al., 2013).

All analyses were carried out using ASReml (Gilmour et al., 2009). For all analyses that involved type traits or predicted LWT, the fixed effects fitted were age and DIM at classification (fitted as covariates), month of calving, and herd-classifier-round (cross classified). The fixed effects fitted when analyzing fertility, production, LL, and survival were herd-year-season of calving, month of calving (as cross classified) and age at calving (as a covariate). For all genetic analyses using sire or animal models, the numerator relationship matrix was constructed using all the available ancestors of sires or animals, depending on the model. The available pedigree information on all animals was traced back to the 1950s, and animals with unknown parents were grouped based on their birth year, country of origin, and sex according to standard ADHIS genetic evaluation procedures (ADHIS, 2004).

\section{RESULTS}

\section{Phenotypic Prediction of LWT}

The best prediction of LWT included 6 type traits: stature, chest width, bone quality, udder depth, central ligament, and muzzle width (Table 3). This model explained $40 \%$ of the observed variation in raw LWT, although this was lower than the coefficient of determination explained by the visually estimated LWT, which was $61 \%$. Figure 1 shows the relationship between actual LWT and visual assessments of LWT. The correlation between actual and predicted LWT and the root mean square error from the 10-fold cross-validation analyses are presented in Table 3. Based on the criteria used to compare the models, our results show that the best type plus BCS model, followed by the best type model, were better predictors of LWT than the other models. However, visually estimated LWT by trained classifiers was better than predicting LWT from type traits based on all the criteria used, except when the root mean square error was used as a criterion. Thus, if phenotypic prediction of LWT is necessary and collecting weight data is difficult, visually assessed LWT of cows is slightly better than that predicted from type traits (Table 3).

Figure 2 shows the distribution of the unadjusted actual (i.e., raw) and predicted LWT of cows based on the best type model. The range in actual LWT of the 932 cows in the data set is more ( 315 to $750 \mathrm{~kg}$ ) than the predicted LWT (315 to 645) using the best type model, showing that these models do not properly fit nor predict extremely large animals. The phenotypic standard deviation of the predicted LWT from the best type model was only $58 \%$ of that observed in measured LWT (Table 1). The standard deviation of the predicted

Table 3. Five models used to predict liveweight and the proportion of variance explained by the model $\left(\mathrm{R}^{2}, \%\right)$ and product-moment correlation (Corr.) and root mean square error (RMSE) from the 10-fold cross-validation

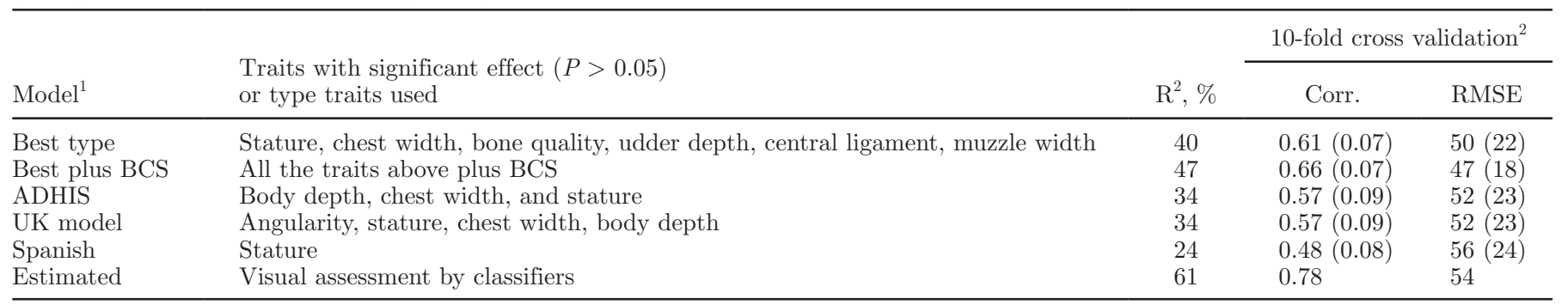

${ }^{1}$ ADHIS = Australian Dairy Herd Improvement Scheme; UK = United Kingdom.

${ }^{2}$ Values in parentheses are SD from the 10-fold validation. 


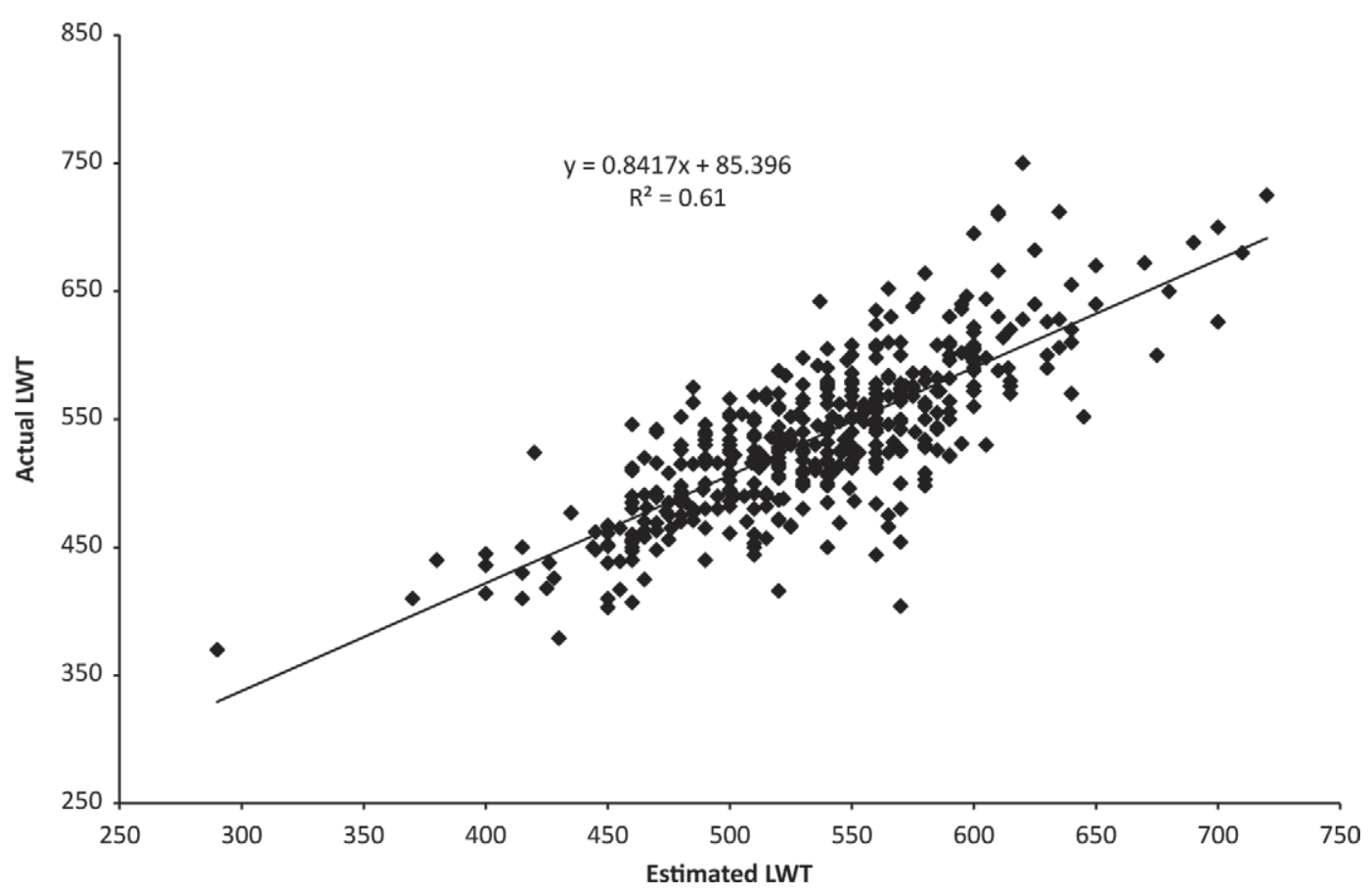

Figure 1. The relationship between actual liveweight (LWT) and visual assessments of LWT.

LWT measures varied from 25 (stature only) to $37 \mathrm{~kg}$ (the best model). Standard deviation of the prediction based on the best model plus BCS was $36 \mathrm{~kg}$, but the prediction was only for cows that calved between 1999 and 2012. On the other hand, the phenotypic standard deviation of the visually assessed LWT was the same as the actual LWT $(63 \mathrm{~kg})$.

After fitting the fixed effects such as herd-roundclassifier, calving year, calving month, age, and DIM at classification in the model, the coefficient of determination for the best model was $72 \%$. Predicted LWT from the current ADHIS model and the UK model were the same because inclusion or exclusion of body depth or angularity did not have any effect on the prediction in the current cow population. Thus, effectively, the prediction in both models was based on stature and chest width and the correlation between the 2 predicted LWT measures from both models was 1.0.

The environmental trend for LWT (adjusted means for year of calving) is shown in Figure 3. The predicted LWT showed some variation over the years, reflecting the environmental circumstances experienced in Eastern Australia over the last 2 decades, which included a prolonged period of drought. For example, the decrease in LWT observed for cows that calved between 2002 and 2007 was possibly associated with drought. Figure 3 also shows that the prediction from the model that only includes stature is less affected by drought conditions.

\section{Relationship of Actual LWT with Type Traits}

Based on cows with LWT data, the heritability of LWT was $0.41 \pm 0.10$ and it had the highest positive genetic correlation with stature and BCS (Table 4). Bone quality, which is mainly a score of flatness of bones (i.e., absence of fat or muscle on the bones), was strongly negatively correlated with LWT. Also, the genetic correlation between angularity and LWT was negative; however, the residual correlation was positive, resulting in a phenotypic correlation of 0 . Most residual correlations in Table 4 were lower than genetic correlations. Due to the small number of cows with LWT data, the standard errors of all estimates were high (0.07 to $0.21)$.

\section{Relationship Among Predicted LWT Measures}

The heritability of predicted LWT varied from 0.31 for LWT predicted based on the best type plus BCS model to 0.42 for LWT predicted based on stature only (Table 5). Genetic correlations among predicted LWT from different models are reasonably high. However, predicted LWT from stature only had a correlation of below 0.8 with the LWT predicted from other models. The genetic correlation of actual LWT with predicted LWT based on the best type plus BCS model was the same as that with the visually estimated LWT (0.88). The genetic correlation of predicted LWT from type 


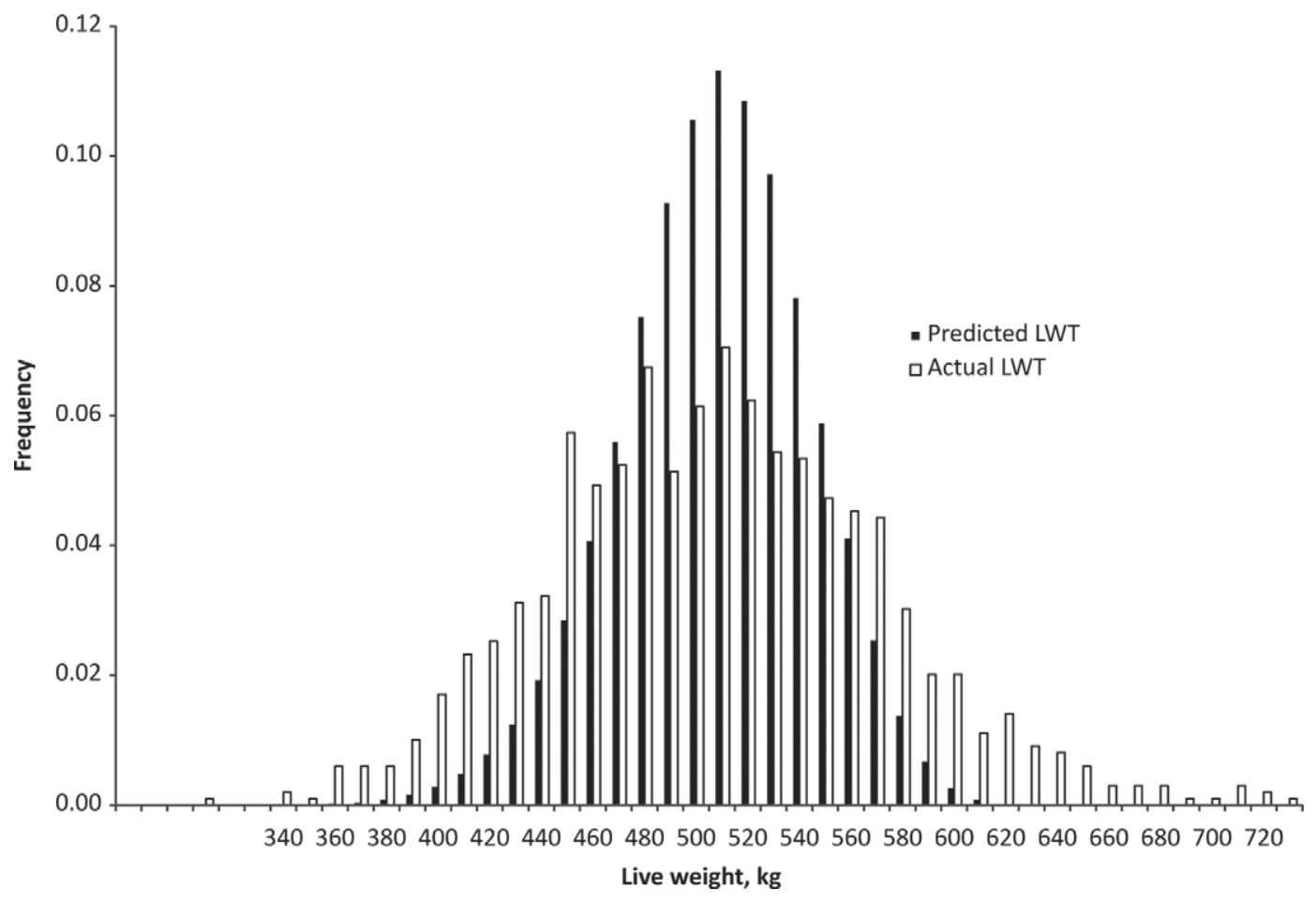

Figure 2. Distribution of the unadjusted actual (i.e., raw) and predicted liveweight (LWT) of cows based on the best type model.

traits were highly correlated with visually estimated LWT, perhaps because type classifiers use similar traits to make their estimation. The residual correlation of actual LWT with predicted LWT based on best type model and best type model plus BCS was lower than its correlation with the visually estimated LWT (Table 5).

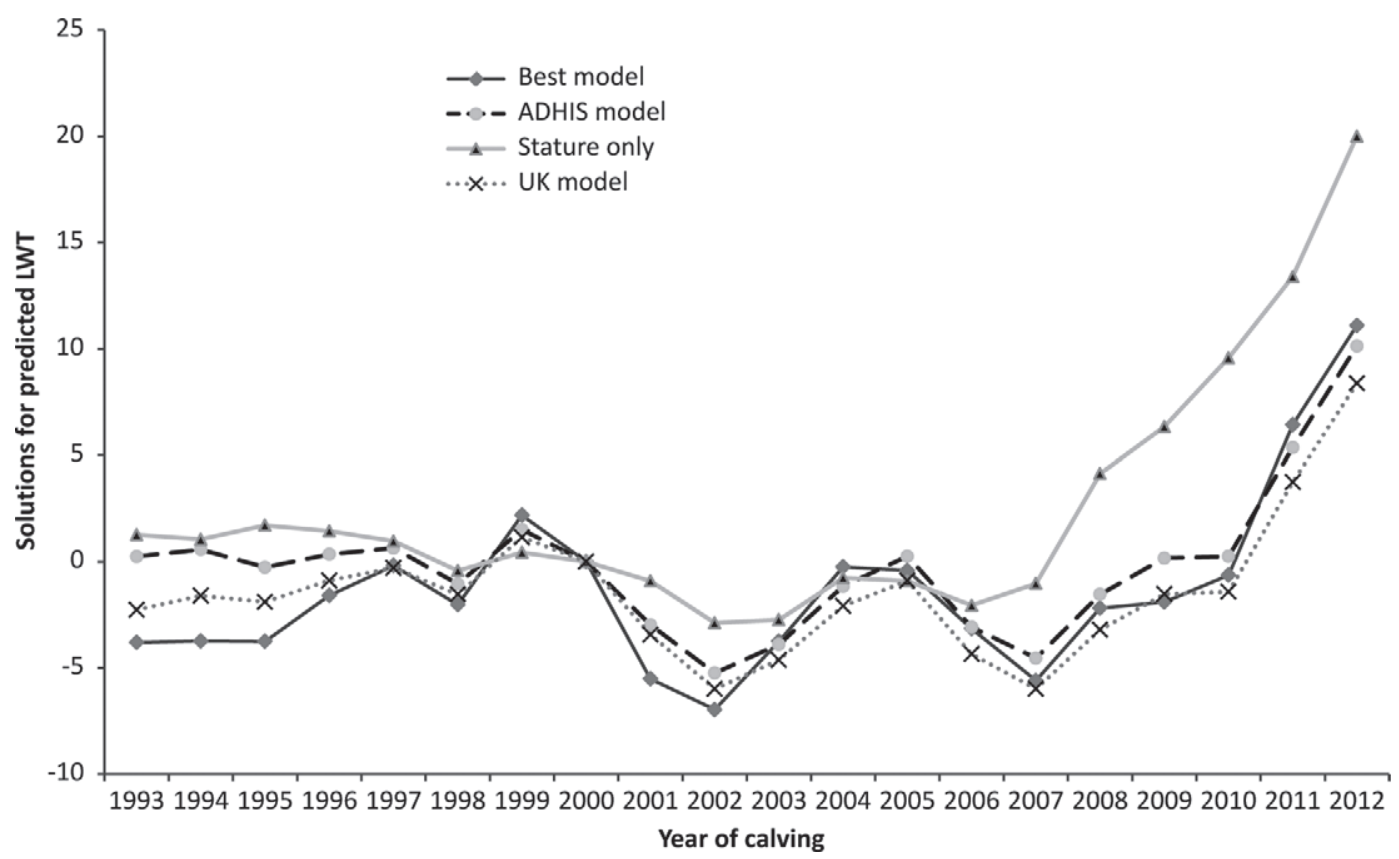

Figure 3. The environmental trend for liveweight (LWT; adjusted means for year of calving). ADHIS = Australian Dairy Herd Improvement Scheme; UK = United Kingdom. 
Table 4. Genetic $\left(r_{g}\right)$ and residual $\left(r_{e}\right)$ correlations (mean \pm SE) between measured liveweight (LWT) and some type traits ${ }^{1}$

\begin{tabular}{lcc}
\hline Trait & \multicolumn{1}{c}{$\mathrm{r}_{\mathrm{g}}$} & $\mathrm{r}_{\mathrm{e}}$ \\
\hline Chest width & $0.40 \pm 0.16$ & $0.28 \pm 0.07$ \\
Stature & $0.65 \pm 0.12$ & $0.31 \pm 0.07$ \\
Bone quality & $-0.78 \pm 0.10$ & $-0.05 \pm 0.09^{\mathrm{NS}}$ \\
Udder depth & $0.32 \pm 0.17$ & $-0.11 \pm 0.08^{\mathrm{NS}}$ \\
Central ligament & $-0.25 \pm 0.20^{\mathrm{NS}}$ & $0.10 \pm 0.07^{\mathrm{NS}}$ \\
Muzzle width & $0.23 \pm 0.17^{\mathrm{NS}}$ & $0.16 \pm 0.08^{\mathrm{NS}}$ \\
Overall type & $-0.20 \pm 0.20^{\mathrm{NS}}$ & $0.25 \pm 0.07$ \\
Body depth & $-0.10 \pm 0.16^{\mathrm{NS}}$ & $0.25 \pm 0.09$ \\
BCS & $0.71 \pm 0.11$ & $0.12 \pm 0.08^{\mathrm{NS}}$ \\
Pin width & $0.12 \pm 0.16^{\mathrm{NS}}$ & $0.21 \pm 0.09^{\mathrm{NS}}$ \\
Angularity & $-0.51 \pm 0.21$ & $0.13 \pm 0.09^{\mathrm{NS}}$ \\
\hline
\end{tabular}

${ }^{1} \mathrm{NS}=$ not significantly different from zero.

The genetic trend in predicted LWT, based on EBV of sires and cows with records and using different measures, shows that predicted LWT has increased by about $0.8 \mathrm{~kg}$ per year (Figure 4). Compared with the genetic trends, environmental trends over the years based on predicted LWT using all models except stature did not show any clear trend (Figure 3). Predicted LWT based on stature only showed a clear increasing environmental trend starting with cows that calved in 2006 .

\section{Relationship of Type Traits with Production and Fitness Traits}

The genetic correlation between type traits and ECM yield varied from -0.45 (udder depth) to 0.39 (angularity), as shown in Table 6. Residual correlations of type traits with all traits were near zero, except the correlation of ECM yield with angularity, body depth, overall type (0.1-0.14), and udder depth $(-0.12)$. The residual correlation of survival with overall type before and after adjusting for ECM yield was also significant (0.10 to 0.12 ), suggesting that farmers practice some level of culling on overall type.

Angularity, body depth, and overall type, which could be used as predictors of LWT, showed moderate genetic correlations with fertility traits such as ClvI and PR. However, the genetic correlations between stature and chest width with ECM yield, fertility traits and survival were close to zero. Traits such as bone quality, central ligament, and muzzle width had lower genetic correlations with ECM yield and fertility than angularity, but higher than stature. Adjusting the type traits for ECM yield reduced their genetic correlation with fertility traits and LL by between 0.02 and 0.06 . For example, in the case of central ligament, its genetic correlation with LL was reduced from 0.20 to 0.16 after adjusting it for ECM yield.

The pattern of correlations of udder depth with production and fitness traits was different from that of other type traits. This trait was unfavorably correlated with ECM yield $(-0.45)$ but favorably correlated with all fitness traits, including survival, and its correlation further increased after adjusting for ECM yield. Even after adjusting for differences in ECM yield, selection for angularity and body depth results in reduced survival. On the other hand, the genetic correlation between overall type and survival was positive both before and after adjusting for ECM yield, suggesting that cows with good overall type remain in herds longer despite their relatively low fertility.

In cows classified from 2007, the definition of angularity and also overall type was modified by HA in an attempt to accommodate their negative correlations with fertility, in particular. However, the analyses of type and fitness traits using the data of cows classified since 2007 showed that the genetic correlations were essentially the same as that for the whole data set (Table 6). The genetic correlation of angularity with ClvI and survival recorded after 2007 was $0.58 \pm 0.08$ and $-0.18 \pm 0.10$, respectively. The corresponding values for overall type were $0.34 \pm 0.10$ and $0.21 \pm 0.10$, respectively, suggesting that the modification of the type classification scheme has not changed the correlations markedly.

Table 5. Genetic parameters for predicted liveweight (LWT; heritability on the diagonal, genetic correlations above diagonal, and residual below diagonal correlation; mean $\pm \mathrm{SE}$ ) for Holstein cows

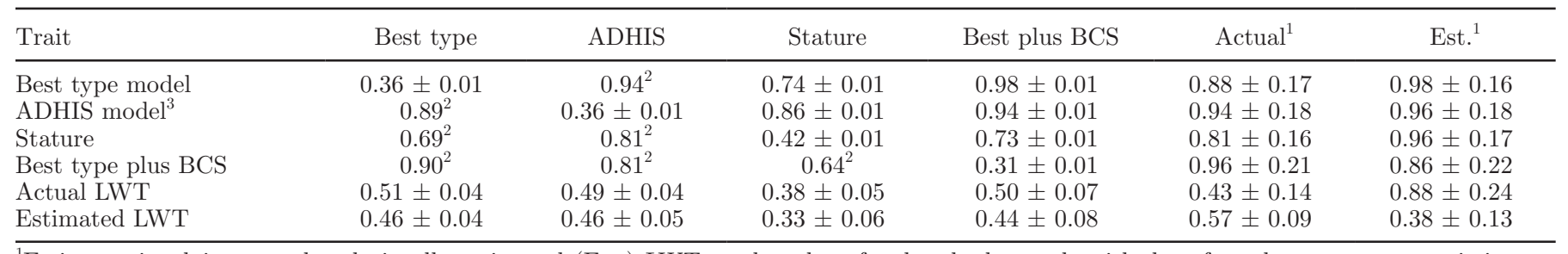

${ }^{1}$ Estimates involving actual and visually estimated (Est.) LWT are based on few hundred records with data for other cows set to missing, so sampling errors may be even higher than tabulated.

${ }^{2}$ Standard errors of residual correlations are rounded to zero.

${ }^{3}$ ADHIS $=$ Australian Dairy Herd Improvement Scheme. 


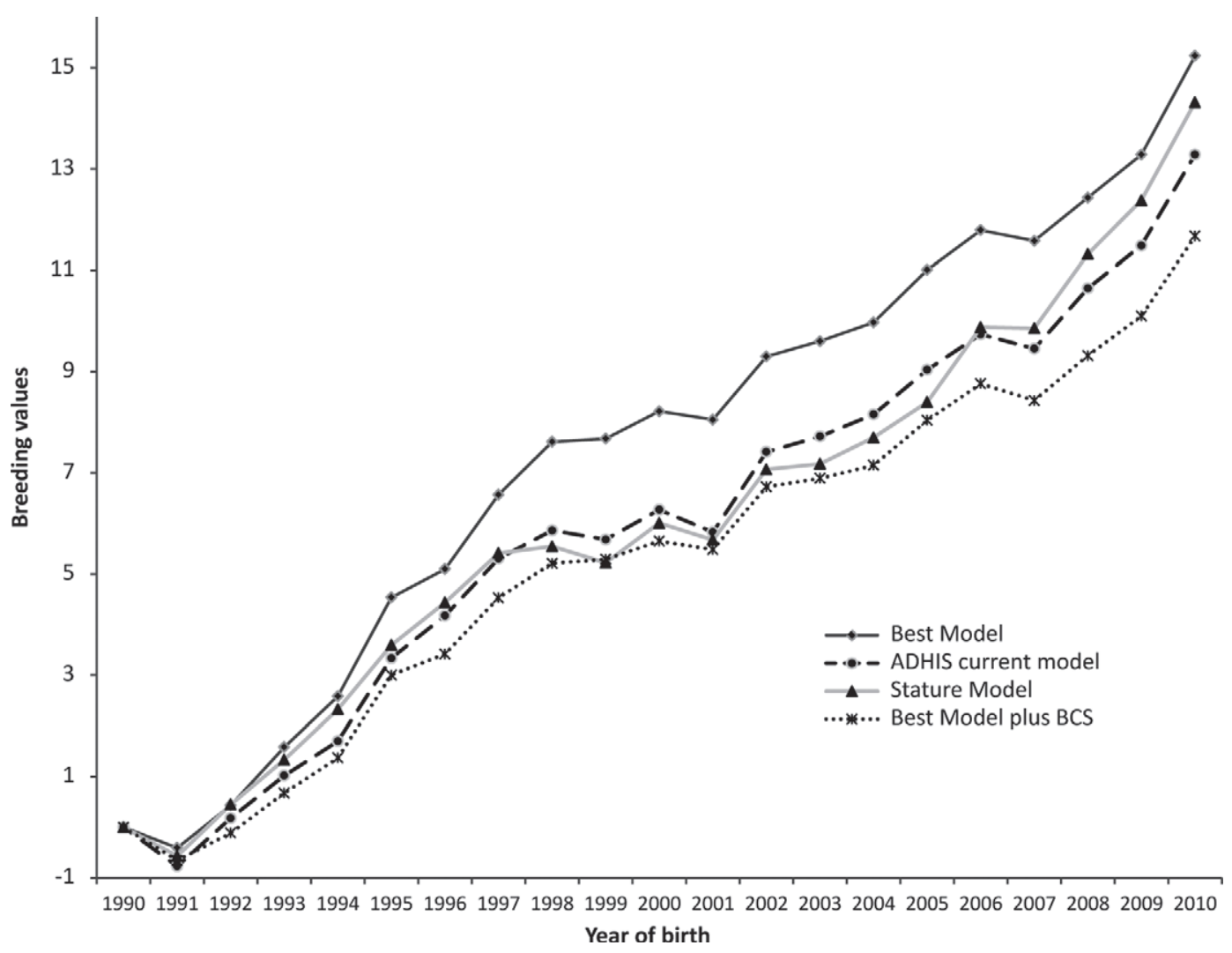

Figure 4. The genetic trend in predicted liveweight (LWT), based on EBV of sires and cows with records and using different measures. ADHIS $=$ Australian Dairy Herd Improvement Scheme.

\section{Relationship of Predicted LWT with Production and Fitness Traits}

Predicted LWT based on stature only was least genetically correlated (0.09) with ECM yield but had a similar correlation (0.14) with ClvI as LWT predicted from the best model including BCS (Table 7). All fertility traits except CFS showed unfavorable correlations with predicted LWT both before and after adjusting for ECM yield. Survival had a correlation that was not different from zero with all measures of predicted LWT both before and after adjustment for ECM yield.

Relationship of Predicted LWT (Selected Type Traits) with Production and Fitness Traits in the Second Lactation. The magnitudes of the genetic correlations of the second-lactation ECM yield with angularity, body depth, udder depth, or overall type (recorded in first lactation) were slightly less accentuated than those in the first lactation (Table 8). Their correlations with fertility traits and survival were also less (by 0.05 to 0.07 ) compared with their correlations in the first lactation but showed that type traits, such as angularity and body depth, measured in the first lactation, had a negative effect on fertility traits measured in later lactations as well. Among fertility traits, the genetic correlation of CFS with body depth and overall type changed from unfavorable $(\sim 0.10)$ in the first lactation to favorable $(-0.3)$ in the second lactation. The correlation of predicted LWT with production and fitness traits was the same as that in the first lactation, except the correlation of CFS with all measures of predicted LWT both before and after adjusting for ECM yield. The genetic correlation of CFS with all predicted LWT measures, body depth, and overall type changed sign from positive (unfavorable) in the first parity to negative (favorable) in the second parity. However, all genetic correlation estimates involving CFS and PR were associated with large standard errors due to limited data.

Relationship of Predicted LWT with Fat-toProtein Ratio (As an Indicator of Metabolic Stress). The genetic correlations of F/P with predicted LWT and other traits show (Table 9) that cows with lower weight and BCS were genetically prone to be metabolically more stressed (higher $\mathrm{F} / \mathrm{P}$ ) than heavier cows or those with good BCS (genetic correlations ranging from -0.07 to -0.12 ). Further, $\mathrm{F} / \mathrm{P}$ seemed to be negatively correlated with PR $(-0.21)$. Table 9 also 
Table 6. Correlations of some type traits associated with liveweight (possible predictors) with ECM yield, fertility traits, and survival before and after adjusting for ECM yield in Australian first-parity Holstein cows

\begin{tabular}{|c|c|c|c|c|c|c|c|c|c|c|c|}
\hline \multirow[b]{3}{*}{ Trait } & \multicolumn{11}{|c|}{ Correlation $^{1,2}$} \\
\hline & \multirow{2}{*}{$\begin{array}{l}\text { With ECM } \\
\text { yield }\end{array}$} & \multicolumn{5}{|c|}{ Fertility and survival before adjusting for ECM yield } & \multicolumn{5}{|c|}{ Fertility and survival after adjusting for ECM yield } \\
\hline & & ClvI & LL & CFS & $\mathrm{PR}$ & Surv & ClvI & $\mathrm{LL}$ & CFS & PR & Surv \\
\hline Angularity & $\begin{array}{c}0.39 \pm 0.04 \\
0.11\end{array}$ & $\begin{array}{c}0.50 \pm 0.04 \\
0.05\end{array}$ & $\begin{array}{c}0.40 \pm 0.05 \\
0.05\end{array}$ & $\begin{array}{c}0.36 \pm 0.08 \\
0.03\end{array}$ & $\begin{array}{l}-0.36 \pm 0.12 \\
-0.02 \pm 0.01\end{array}$ & $\begin{array}{c}-0.15 \pm 0.05 \\
0.02\end{array}$ & $\begin{array}{c}0.47 \pm 0.04 \\
0.01\end{array}$ & $\begin{array}{l}0.35 \pm 0.05 \\
-0.0\end{array}$ & $\begin{array}{c}0.33 \pm 0.08 \\
0.01\end{array}$ & $\begin{array}{l}-0.27 \pm 0.08 \\
-0.01 \pm 0.01\end{array}$ & $\begin{array}{c}-0.19 \pm 0.05 \\
0.0\end{array}$ \\
\hline Stature & $\begin{array}{c}0.10 \pm 0.04 \\
0.08\end{array}$ & $\begin{array}{c}0.15 \pm 0.05 \\
0.01\end{array}$ & $\begin{array}{c}0.10 \pm 0.05 \\
0.02\end{array}$ & $\begin{array}{c}-0.09 \pm 0.08 \\
0.0\end{array}$ & $\begin{array}{r}-0.02 \pm 0.12 \\
0.01 \pm 0.01\end{array}$ & $\begin{array}{c}0.06 \pm 0.04 \\
0.03\end{array}$ & $\begin{array}{l}0.12 \pm 0.05 \\
-0.03\end{array}$ & $\begin{array}{c}0.06 \pm 0.05 \\
-0.04\end{array}$ & $\begin{array}{c}-0.12 \pm 0.08 \\
-0.01\end{array}$ & $\begin{array}{l}0.05 \pm 0.08 \\
0.02 \pm 0.01\end{array}$ & $\begin{array}{c}0.05 \pm 0.04 \\
0.02\end{array}$ \\
\hline Body depth & $\begin{array}{c}0.37 \pm 0.03 \\
0.12\end{array}$ & $\begin{array}{c}0.40 \pm 0.04 \\
0.02\end{array}$ & $\begin{array}{c}0.31 \pm 0.05 \\
0.04\end{array}$ & $\begin{array}{c}0.15 \pm 0.08 \\
-0.01\end{array}$ & $\begin{array}{l}-0.48 \pm 0.10 \\
-0.01 \pm 0.01\end{array}$ & $\begin{array}{c}-0.18 \pm 0.04 \\
0.03\end{array}$ & $\begin{array}{l}0.37 \pm 0.04 \\
-0.03\end{array}$ & $\begin{array}{c}0.26 \pm 0.05 \\
-0.04\end{array}$ & $\begin{array}{c}0.12 \pm 0.08 \\
-0.03\end{array}$ & $\begin{array}{r}-0.40 \pm 0.07 \\
0.01 \pm 0.01\end{array}$ & $\begin{array}{c}-0.20 \pm 0.05 \\
0.02\end{array}$ \\
\hline Chest width & $\begin{array}{c}0.15 \pm 0.04 \\
0.04\end{array}$ & $\begin{array}{c}0.05 \pm 0.05 \\
-0.02\end{array}$ & $\begin{array}{c}0.05 \pm 0.05 \\
-0.0\end{array}$ & $\begin{array}{c}-0.16 \pm 0.08 \\
-0.04\end{array}$ & $\begin{array}{r}-0.19 \pm 0.11 \\
0.02 \pm 0.01\end{array}$ & $\begin{array}{c}-0.0 \pm 0.05 \\
0.04\end{array}$ & $\begin{array}{l}0.03 \pm 0.05 \\
-0.05\end{array}$ & $\begin{array}{c}0.02 \pm 0.05 \\
-0.04\end{array}$ & $\begin{array}{c}-0.18 \pm 0.08 \\
-0.05\end{array}$ & $\begin{array}{r}-0.18 \pm 0.08 \\
0.03 \pm 0.01\end{array}$ & $\begin{array}{c}-0.01 \pm 0.05 \\
0.03\end{array}$ \\
\hline Bone quality & $\begin{array}{c}0.18 \pm 0.04 \\
0.05\end{array}$ & $\begin{array}{c}0.24 \pm 0.05 \\
0.04\end{array}$ & $\begin{array}{c}0.22 \pm 0.05 \\
0.03\end{array}$ & $\begin{array}{c}0.25 \pm 0.08 \\
0.03\end{array}$ & $\begin{array}{l}-0.10 \pm 0.12 \\
-0.01 \pm 0.01\end{array}$ & $\begin{array}{c}0.04 \pm 0.04 \\
0.0\end{array}$ & $\begin{array}{c}0.22 \pm 0.05 \\
0.02\end{array}$ & $\begin{array}{c}0.20 \pm 0.05 \\
0.01\end{array}$ & $\begin{array}{c}0.24 \pm 0.08 \\
0.03\end{array}$ & $\begin{array}{l}-0.02 \pm 0.08 \\
-0.00 \pm 0.01\end{array}$ & $\begin{array}{c}0.02 \pm 0.04 \\
-0.0\end{array}$ \\
\hline Udder depth & $\begin{array}{c}-0.45 \pm 0.03 \\
-0.12\end{array}$ & $\begin{array}{c}-0.20 \pm 0.04 \\
-0.01\end{array}$ & $\begin{array}{c}-0.19 \pm 0.05 \\
-0.03\end{array}$ & $\begin{array}{c}-0.36 \pm 0.08 \\
-0.0\end{array}$ & $\begin{array}{r}0.16 \pm 0.11 \\
-0.01 \pm 0.01\end{array}$ & $\begin{array}{c}0.19 \pm 0.04 \\
0.0\end{array}$ & $\begin{array}{c}-0.16 \pm 0.05 \\
0.04\end{array}$ & $\begin{array}{c}-0.14 \pm 0.05 \\
0.05\end{array}$ & $\begin{array}{c}-0.34 \pm 0.08 \\
0.02\end{array}$ & $\begin{array}{l}0.19 \pm 0.08 \\
0.02 \pm 0.01\end{array}$ & $\begin{array}{c}0.22 \pm 0.04 \\
0.02\end{array}$ \\
\hline Muzzle width & $\begin{array}{c}0.23 \pm 0.04 \\
0.06\end{array}$ & $\begin{array}{c}0.23 \pm 0.05 \\
0.01\end{array}$ & $\begin{array}{c}0.18 \pm 0.05 \\
0.01\end{array}$ & $\begin{array}{c}-0.02 \pm 0.08 \\
-0.01\end{array}$ & $\begin{array}{r}-0.24 \pm 0.11 \\
0.01 \pm 0.01\end{array}$ & $\begin{array}{c}-0.11 \pm 0.05 \\
0.02\end{array}$ & $\begin{array}{l}0.21 \pm 0.05 \\
-0.02\end{array}$ & $\begin{array}{l}0.14 \pm 0.05 \\
-0.03\end{array}$ & $\begin{array}{c}-0.04 \pm 0.08 \\
-0.02\end{array}$ & $\begin{array}{r}-0.23 \pm 0.08 \\
0.01 \pm 0.01\end{array}$ & $\begin{array}{c}-0.12 \pm 0.05 \\
0.02\end{array}$ \\
\hline Overall type & $\begin{array}{c}0.33 \pm 0.04 \\
0.14\end{array}$ & $\begin{array}{c}0.38 \pm 0.05 \\
0.04\end{array}$ & $\begin{array}{c}0.40 \pm 0.05 \\
0.08\end{array}$ & $\begin{array}{c}0.13 \pm 0.09 \\
0.01\end{array}$ & $\begin{array}{r}-0.24 \pm 0.13 \\
0.01 \pm 0.01\end{array}$ & $\begin{array}{c}0.23 \pm 0.05 \\
0.12\end{array}$ & $\begin{array}{c}0.33 \pm 0.05 \\
-0.01\end{array}$ & $\begin{array}{c}0.32 \pm 0.05 \\
0.0\end{array}$ & $\begin{array}{c}0.08 \pm 0.09 \\
-0.01\end{array}$ & $\begin{array}{l}0.02 \pm 0.08 \\
0.05 \pm 0.01\end{array}$ & $\begin{array}{c}0.20 \pm 0.05 \\
0.10\end{array}$ \\
\hline Central ligament & $\begin{array}{c}0.19 \pm 0.04 \\
0.07\end{array}$ & $\begin{array}{c}0.18 \pm 0.05 \\
0.04\end{array}$ & $\begin{array}{c}0.20 \pm 0.05 \\
0.05\end{array}$ & $\begin{array}{c}0.09 \pm 0.08 \\
0.03\end{array}$ & $\begin{aligned}-0.03 & \pm 0.08 \\
0.0 & \pm 0.01\end{aligned}$ & $\begin{array}{c}0.10 \pm 0.05 \\
0.05\end{array}$ & $\begin{array}{c}0.16 \pm 0.05 \\
0.02\end{array}$ & $\begin{array}{c}0.16 \pm 0.05 \\
0.02\end{array}$ & $\begin{array}{c}0.08 \pm 0.08 \\
0.02\end{array}$ & $\begin{aligned}-0.03 & \pm 0.09 \\
0.01 & \pm 0.01\end{aligned}$ & $\begin{array}{c}0.09 \pm 0.05 \\
0.04\end{array}$ \\
\hline
\end{tabular}

${ }^{1} \mathrm{ClvI}=$ calving interval; $\mathrm{LL}=$ lactation length; $\mathrm{CFS}=$ calving to first service; $\mathrm{PR}=$ pregnancy rate; Surv = survival.

${ }^{2}$ The first row is the genetic correlation and the second row is the residual correlation. Standard errors of residual correlations are rounded to zero. 
shows that angularity, which was chosen as a possible indicator of metabolic stress, was positively genetically correlated with $\mathrm{F} / \mathrm{P}$, although this correlation had a large standard error.

\section{DISCUSSION}

The main objectives of this study were 2 -fold: 1 ) to provide a best-prediction of LWT in Australia using linear type traits and 2) to examine if continued selection on a breeding objective that includes LWT with a negative economic weight could have a negative effect on fitness traits.

\section{Phenotypic Prediction of LWT}

Cow LWT was predicted from type traits that included stature, chest width, bone quality, udder depth, central ligament, and muzzle width. Most of these traits have been used to predict LWT by others (e.g., Tsuruta et al., 2004; Banos and Coffey, 2012). For example, Banos and Coffey (2012) found that chest width, stature, body depth, angularity, and central ligament had significant effects on LWT. The low correlation between actual and predicted LWT and the high root mean square errors from the cross-validation in the current study compared with those of Banos and Coffey (2012) in the UK could be due to the following 3 main differences. First, in the current study, cows were weighed only once. Second, whereas Banos and Coffey (2012) fitted age at classification, we did not include any fixed effect in our model, preferring to fit all important fixed effects when analyzing the predicted LWT measure itself. Third, the data used by Banos and Coffey (2012) were from a single research herd where management might have been more uniform. In contrast, the data in our study were from cows on commercial farms.

Although predictions based on several traits were compared, a reasonably good prediction of LWT can be made using a few key traits, as is current practice in Australia (the ADHIS model; Table 4). The most important predictors of LWT in the current study were chest width and stature because these traits explain different aspects of size and bone quality, which is a measure of flatness of the bone associated with lack of muscle and fat reserves. Adding BCS, which has a high and negative correlation with bone quality and angularity (Haile-Mariam et al., 2013), improved the prediction of LWT; however, it was only available for a limited number of cows that participated in type classification after 1998. In Australian data (Haile-Mariam et al., 2013), the genetic correlation of bone quality $(-0.76)$ with BCS is slightly higher than that with angularity $(-0.70)$. 
Table 8. Correlations of type traits and predicted liveweight (LWT) with ECM yield, fertility traits, and survival before and after adjusting for ECM yield in second-lactation Australian Holstein cows

Correlation $^{1,2}$

\begin{tabular}{|c|c|c|c|c|c|c|c|c|c|c|c|}
\hline \multirow{2}{*}{$\begin{array}{l}\text { Type/predicted } \\
\text { LWT }\end{array}$} & \multirow{2}{*}{$\begin{array}{c}\text { With ECM } \\
\text { yield }\end{array}$} & \multicolumn{5}{|c|}{ Fertility and survival before adjusting for ECM yield } & \multicolumn{5}{|c|}{ Fertility and survival after adjusting for ECM yield } \\
\hline & & ClvI & LL & CFS & PR & Surv & ClvI & LL & CFS & $\mathrm{PR}$ & Surv \\
\hline Angularity & $\begin{array}{c}0.23 \pm 0.05 \\
0.05\end{array}$ & $\begin{array}{c}0.43 \pm 0.06 \\
0.04\end{array}$ & $\begin{array}{c}0.35 \pm 0.07 \\
0.04\end{array}$ & $\begin{array}{l}0.29 \pm 0.18 \\
0.02 \pm 0.01\end{array}$ & $\begin{array}{l}-0.23 \pm 0.14 \\
-0.02 \pm 0.01\end{array}$ & $\begin{array}{c}-0.13 \pm 0.07 \\
-0.0\end{array}$ & $\begin{array}{c}0.41 \pm 0.06 \\
0.02\end{array}$ & $\begin{array}{c}0.33 \pm 0.07 \\
0.01\end{array}$ & $\begin{array}{l}0.27 \pm 0.18 \\
0.02 \pm 0.01\end{array}$ & $\begin{array}{l}-0.22 \pm 0.14 \\
-0.02 \pm 0.01\end{array}$ & $\begin{array}{c}-0.13 \pm 0.07 \\
-0.0\end{array}$ \\
\hline Body depth & $\begin{array}{c}0.30 \pm 0.04 \\
0.08\end{array}$ & $\begin{array}{c}0.45 \pm 0.06 \\
0.05\end{array}$ & $\begin{array}{c}0.28 \pm 0.07 \\
0.04\end{array}$ & $\begin{array}{c}-0.25 \pm 0.20 \\
0.02\end{array}$ & $\begin{array}{l}-0.41 \pm 0.12 \\
-0.03 \pm 0.01\end{array}$ & $\begin{array}{c}-0.31 \pm 0.06 \\
-0.01\end{array}$ & $\begin{array}{c}0.43 \pm 0.06 \\
0.02\end{array}$ & $\begin{array}{c}0.25 \pm 0.07 \\
-0.01\end{array}$ & $\begin{aligned}-0.28 & \pm 0.20 \\
0.01 & \pm 0.01\end{aligned}$ & $\begin{array}{l}-0.41 \pm 0.13 \\
-0.02 \pm 0.01\end{array}$ & $\begin{array}{c}-0.32 \pm 0.06 \\
-0.02\end{array}$ \\
\hline Udder depth & $\begin{array}{c}-0.31 \pm 0.04 \\
-0.04\end{array}$ & $\begin{array}{c}-0.14 \pm 0.06 \\
-0.01\end{array}$ & $\begin{array}{c}-0.07 \pm 0.07 \\
-0.0\end{array}$ & $\begin{aligned}-0.33 & \pm 0.19 \\
-0.0 & \pm 0.01\end{aligned}$ & $\begin{array}{l}0.31 \pm 0.12 \\
0.02 \pm 0.01\end{array}$ & $\begin{array}{c}0.33 \pm 0.06 \\
0.03\end{array}$ & $\begin{array}{c}-0.12 \pm 0.07 \\
0.01\end{array}$ & $\begin{array}{c}-0.05 \pm 0.07 \\
0.03\end{array}$ & $\begin{array}{r}-0.32 \pm 0.19 \\
0.01 \pm 0.01\end{array}$ & $\begin{array}{l}0.30 \pm 0.12 \\
0.01 \pm 0.01\end{array}$ & $\begin{array}{c}0.33 \pm 0.06 \\
0.04\end{array}$ \\
\hline Overall type & $\begin{array}{c}0.28 \pm 0.05 \\
0.08\end{array}$ & $\begin{array}{c}0.40 \pm 0.07 \\
0.04\end{array}$ & $\begin{array}{c}0.39 \pm 0.07 \\
0.05\end{array}$ & $\begin{aligned}-0.26 & \pm 0.23 \\
0.02 & \pm 0.01\end{aligned}$ & $\begin{aligned}-0.12 & \pm 0.14 \\
0.02 & \pm 0.01\end{aligned}$ & $\begin{array}{c}0.15 \pm 0.07 \\
0.05\end{array}$ & $\begin{array}{c}0.37 \pm 0.07 \\
0.01\end{array}$ & $\begin{array}{c}0.36 \pm 0.07 \\
0.0\end{array}$ & $\begin{aligned}-0.29 & \pm 0.23 \\
0.01 & \pm 0.01\end{aligned}$ & $\begin{aligned}-0.11 & \pm 0.14 \\
0.02 & \pm 0.01\end{aligned}$ & $\begin{array}{c}0.14 \pm 0.07 \\
0.04\end{array}$ \\
\hline Best type & $\begin{array}{c}0.30 \pm 0.05 \\
0.09\end{array}$ & $\begin{array}{c}0.30 \pm 0.07 \\
0.02\end{array}$ & $\begin{array}{c}0.19 \pm 0.07 \\
0.03\end{array}$ & $\begin{aligned}-0.45 & \pm 0.20 \\
0.02 & \pm 0.01\end{aligned}$ & $\begin{array}{l}-0.29 \pm 0.13 \\
-0.01 \pm 0.01\end{array}$ & $\begin{array}{c}-0.05 \pm 0.06 \\
0.01\end{array}$ & $\begin{array}{l}0.27 \pm 0.07 \\
\quad-0.02\end{array}$ & $\begin{array}{l}0.15 \pm 0.07 \\
\quad-0.03\end{array}$ & $\begin{aligned}-0.48 & \pm 0.20 \\
0.01 & \pm 0.01\end{aligned}$ & $\begin{array}{r}-0.28 \pm 0.13 \\
-0.0 \pm 0.01\end{array}$ & $\begin{array}{c}-0.06 \pm 0.06 \\
0.0\end{array}$ \\
\hline ADHIS $^{3}$ & $\begin{array}{c}0.24 \pm 0.05 \\
0.08\end{array}$ & $\begin{array}{c}0.25 \pm 0.07 \\
0.02\end{array}$ & $\begin{array}{c}0.13 \pm 0.07 \\
0.02\end{array}$ & $\begin{aligned}-0.43 & \pm 0.21 \\
0.02 & \pm 0.01\end{aligned}$ & $\begin{array}{l}-0.33 \pm 0.13 \\
-0.02 \pm 0.01\end{array}$ & $\begin{array}{c}-0.08 \pm 0.06 \\
0.0\end{array}$ & $\begin{array}{l}0.23 \pm 0.07 \\
\quad-0.01\end{array}$ & $\begin{array}{c}0.09 \pm 0.07 \\
-0.03\end{array}$ & $\begin{aligned}-0.46 & \pm 0.21 \\
0.01 & \pm 0.01\end{aligned}$ & $\begin{array}{l}-0.33 \pm 0.13 \\
-0.01 \pm 0.01\end{array}$ & $\begin{array}{c}-0.09 \pm 0.06 \\
-0.01\end{array}$ \\
\hline Stature only & $\begin{array}{c}0.11 \pm 0.05 \\
0.06\end{array}$ & $\begin{array}{c}0.13 \pm 0.07 \\
0.01\end{array}$ & $\begin{array}{c}0.02 \pm 0.07 \\
0.01\end{array}$ & $\begin{aligned}-0.24 & \pm 0.19 \\
0.01 & \pm 0.01\end{aligned}$ & $\begin{array}{c}-0.04 \pm 0.13 \\
-0.0\end{array}$ & $\begin{array}{c}0.01 \pm 0.06 \\
-0.02\end{array}$ & $\begin{array}{l}0.12 \pm 0.07 \\
\quad-0.01\end{array}$ & $\begin{array}{c}-0.01 \pm 0.07 \\
-0.03\end{array}$ & $\begin{aligned}-0.26 & \pm 0.19 \\
0.0 & \pm 0.01\end{aligned}$ & $\begin{array}{l}-0.03 \pm 0.13 \\
-0.01 \pm 0.01\end{array}$ & $\begin{array}{c}0.0 \pm 0.06 \\
-0.01\end{array}$ \\
\hline Best type plus BCS & $\begin{array}{c}0.26 \pm 0.05 \\
0.08\end{array}$ & $\begin{array}{c}0.18 \pm 0.08 \\
0.02\end{array}$ & $\begin{array}{c}0.08 \pm 0.08 \\
0.02\end{array}$ & $\begin{array}{l}-0.55 \pm 0.17 \\
-0.02 \pm 0.01\end{array}$ & $\begin{array}{r}-0.18 \pm 0.14 \\
-0.0 \pm 0.01\end{array}$ & $\begin{array}{c}0.04 \pm 0.08 \\
0.01\end{array}$ & $\begin{array}{l}0.16 \pm 0.08 \\
\quad-0.01\end{array}$ & $\begin{array}{l}0.05 \pm 0.09 \\
-0.02\end{array}$ & $\begin{aligned}-0.57 & \pm 0.17 \\
0.01 & \pm 0.01\end{aligned}$ & $\begin{aligned}-0.17 & \pm 0.14 \\
0.0 & \pm 0.01\end{aligned}$ & $\begin{array}{c}0.03 \pm 0.08 \\
0.01\end{array}$ \\
\hline
\end{tabular}

${ }^{1} \mathrm{ClvI}=$ calving interval; $\mathrm{LL}=$ lactation length; $\mathrm{CFS}=$ calving to first service; $\mathrm{PR}=$ pregnancy rate; Surv = survival.

${ }^{2}$ First row is genetic correlation and second row is residual correlation. Standard errors of residual correlations are rounded to zero.

${ }^{3}$ Australian Dairy Herd Improvement Scheme. 
Table 9. Genetic $\left(\mathrm{r}_{\mathrm{g}}\right)$ and residual $\left(\mathrm{r}_{\mathrm{e}}\right)$ correlation of predicted liveweight (LWT), production, and fitness traits with fat-to-protein ratio before and after adjusting for ECM yield

\begin{tabular}{|c|c|c|c|c|}
\hline \multirow[b]{3}{*}{ Trait } & \multicolumn{4}{|c|}{ Correlation $^{1}$} \\
\hline & \multicolumn{2}{|c|}{ Before adjusting for ECM yield } & \multicolumn{2}{|c|}{ After adjusting for ECM yield } \\
\hline & $r_{g}$ & $\mathrm{r}_{\mathrm{e}}$ & $\mathrm{r}_{\mathrm{g}}$ & $\mathrm{r}_{\mathrm{e}}$ \\
\hline Best type & $-0.12 \pm 0.03$ & -0.03 & $-0.13 \pm 0.03$ & -0.03 \\
\hline $\mathrm{ADHIS}^{2}$ & $-0.09 \pm 0.03$ & -0.02 & $-0.09 \pm 0.03$ & -0.02 \\
\hline Stature only & $-0.07 \pm 0.03$ & -0.04 & $-0.07 \pm 0.03$ & -0.04 \\
\hline Best type plus BCS & $-0.13 \pm 0.03$ & -0.03 & $-0.13 \pm 0.03$ & -0.03 \\
\hline BCS & $-0.08 \pm 0.03$ & 0.0 & $-0.08 \pm 0.03$ & 0.0 \\
\hline Angularity & $0.08 \pm 0.03$ & 0.02 & $0.08 \pm 0.03$ & 0.02 \\
\hline Calving interval & $0.05 \pm 0.04$ & -0.02 & $\mathrm{NE}^{3}$ & \\
\hline Lactation length & $-0.08 \pm 0.04$ & -0.04 & $\mathrm{NE}$ & \\
\hline Calving to first service & $0.07 \pm 0.07$ & -0.04 & $\mathrm{NE}$ & \\
\hline Survival & $-0.09 \pm 0.04$ & -0.01 & $\mathrm{NE}$ & \\
\hline Pregnancy rate & $-0.21 \pm 0.07$ & -0.0 & $\mathrm{NE}$ & \\
\hline ECM yield & $0.04 \pm 0.03$ & 0.0 & $\mathrm{NE}$ & \\
\hline
\end{tabular}

${ }^{1}$ Standard errors of residual correlations are rounded to zero.

${ }^{2}$ Australian Dairy Herd Improvement Scheme.

${ }^{3} \mathrm{NE}=$ not estimated.

The correlations between LWT EBV calculated by ADHIS (i.e., national evaluation) of 5,541 bulls and their EBV calculated in the current study were 0.80 , $0.87,0.72$, and 0.82 when LWT was predicted using the best type, the ADHIS, stature, and best type plus BCS models, respectively. In general, genetic evaluations based on the different models including visually estimated LWT are likely to be similar, given the high genetic correlations (Table 5), but phenotypic prediction of LWT from type traits would have a low reliability. One of the limitations with actual LWT data is that they are not independent of gut fill. So, there could be some merit in visually assessed LWT or predicted LWT from type traits, even compared with actual measured LWT, because it is possible to account for difference in gut fill as well as having a LWT measure that is also independent of body fatness, by adjusting for BCS.

The average LWT in Australian Holstein cows (510 $\mathrm{kg}$ ) is lower than most other countries. For example, Berry et al. (2003) reported a mean LWT of $558 \mathrm{~kg}$ for first-parity Irish Holstein cows. Becker et al. (2012) reported postpartum BW of 615 and $556 \mathrm{~kg}$ in large and small lines of Holsteins, respectively, in the United States. Part of the reason for low LWT in the Australian Holstein could be that the predominant feeding system in Australia is grazing grass. In support of this, Coffey et al. (2003) observed close to 35-kg differences between grazed and housed cows in the UK.

The heritability of LWT in the current study $(\sim 0.4)$ is within the range of estimates in other studies (Berry et al., 2003; Banos and Coffey, 2012). The heritability of LWT in the current study was also similar to that reported by Madgwick et al. (1991) based on Australian data collected in the 1980s. The heritability of pre- dicted LWT from type traits in the current study were also similar to other studies (Pérez-Cabal and Alenda, 2003; Tsuruta et al., 2004), which used similar type traits to predict LWT.

The genetic correlation of LWT with type traits in the current study were similar to those reported by Veerkamp and Brotherstone (1997) and Banos and Coffey (2012) in the UK but lower than those by Vallimont et al. (2010) in the United States. The genetic correlations of LWT with stature and strength (a trait similar to chest width) of 0.94 and 0.84 , respectively, were reported by Vallimont et al. (2010).

The observed genetic trend of predicted LWT in the current study $(0.8 \mathrm{~kg} / \mathrm{yr})$ was higher than that observed $(\sim 0.3 \mathrm{~kg} / \mathrm{yr})$ in New Zealand dairy cattle after the inclusion of LWT in their economic index, but lower than those observed before selection for reduced LWT $(\sim 1.5 \mathrm{~kg} / \mathrm{yr})$ was introduced (Harris et al. 2007). A genetic trend of about $1.4 \mathrm{~kg}$ per year was reported by Pérez-Cabal et al. (2006) in Spanish Holstein cows where stature was used to predict LWT. In Australia, if all selection decisions were based on APR that include EBV on predicted LWT (in addition to 8 other traits that affect profitability), the genetic response per year could be predicted using selection index theory (Hazel, 1943). When this was calculated using the multitrait selection index software of J. van der Werf (http:// www-personal.une.edu.au/ jvanderw/software.htm) that considers the 4 pathways of selection of Robertson and Rendel (1950; i.e., assuming an optimal progeny test scheme where the response to selection of the breeding objective is 0.25 genetic SD per year), then the expected response in LWT was $1.2 \mathrm{~kg}$ per year when LWT was in the breeding objective and $1.5 \mathrm{~kg}$ per year 
if LWT was excluded from the breeding objective. The observed genetic trend of 0.8 per year in predict LWT (Figure 4) was lower than predicted using the selection index, possibly due to a small downward trend in chest width and BCS and also a small positive trend in bone quality (Haile-Mariam et al., 2013), which was unfavorably correlated with LWT (Table 4). However, the discrepancy between the expected and observed trend could also be because all selection is not based on APR.

\section{Relationship of Predicted LWT with Production}

The positive genetic correlation estimate between ECM yield and predicted LWT agrees with most literature estimates, suggesting that bigger cows produce slightly more milk (Pérez-Cabal and Alenda, 2003; Tsuruta et al., 2004; Wall et al., 2007). However, the correlation between LWT and milk yield is influenced by stage of lactation when measurements of LWT or predictors are taken and on whether actual LWT or predicted LWT is used (Veerkamp, 1998). In the current study, the average age and DIM at classification was $32 \mathrm{mo}$ and $130 \mathrm{~d}$, respectively. Given the average stage of lactation when cows were classified, the genetic correlation between predicted LWT and milk production traits should be negative or near zero (Veerkamp, 1998; Wall et al., 2007). The fact that the correlations were positive in the current study may be due to the use of type data to predict LWT or other unique genetic and environmental circumstances. The genetic correlation between ECM yield and predicted LWT based on the best type model was slightly higher $(0.36 \pm 0.06)$ in low-LWT cows (i.e., cows with predicted LWT of below $510 \mathrm{~kg}$, on average) than in high-LWT cows (0.24 \pm 0.06). The genetic correlation between LWT and milk yield based on Australian data of cows that calved in 1980s was also positive (0.32; Madgwick et al., 1991). Type traits that had the highest correlations (body depth, angularity, and overall type) with ECM yield in the current study were also highly correlated in other studies (Wall et al., 2007).

\section{Relationship of Predicted LWT with Fertility}

In general, the genetic correlation estimates of predicted LWT with fertility traits from the current study were in agreement with other studies (Hansen et al., 1999; Berry et al., 2003). Large cows are prone to have impaired fertility compared with small cows. The exception to this is the genetic correlation of predicted LWT with CFS (Table 7), which agrees with Berry et al. (2003) who also found that cows with higher predicted LWT showed a shorter calving-to-mating interval. However, in both studies, early mating did not translate into shorter ClvI or higher PR. Thus, heavier cows are likely to be less fertile even after adjusting for differences in milk yield. The correlation between EBV based on predicted LWT from the best type model and fertility EBV calculated using the national data by ADHIS were negative $(-0.13)$, in agreement with the estimates from variance-covariance analyses.

In New Zealand, where most of the LWT data are collected using scales (Montgomerie, 2007), the genetic correlations of LWT with mating rate within $21 \mathrm{~d}$ after the start of mating date and calving rate within $42 \mathrm{~d}$ after the start of the planned calving date were 0.17 and 0.02, respectively (e.g., Pryce and Harris, 2006). As the first fertility trait is a measure of showing heat and mating early, its positive correlation is in agreement with Berry et al. (2003) and the current results. However, the positive or near-zero correlation between measured LWT and fertility in New Zealand data could be due to the fact that BCS is an important component of LWT (i.e., genetic correlation of 0.71) and BCS has a positive correlation with fertility (Pryce and Harris, 2006). The effect of including BCS as an additional predictor of LWT can also be observed in the current study by comparing, for example, the genetic correlation of ClvI with predicted LWT that included BCS and ignored BCS (Table 7). Thus, the genetic correlation between predicted LWT based on different type traits and fertility reflect the relationship of the combined effect (both negative and positive) of type traits with fertility.

The near-zero genetic correlation of stature and chest width with fertility in the current study compares well with those in the UK (Wall et al., 2007) and does not support the observation that cows with big stature are less fertile. This is also in agreement with Pérez-Cabal and Alenda (2003), who found that the genetic correlation between ClvI and BW predicted from stature was near zero (0.07).

As in the current study, Wall et al. (2007) also found that among type traits that could be used for predicting LWT, body depth, and angularity were unfavorably correlated with fertility. The approximate genetic correlation of -0.56 between PR and muzzle width (based on EBV) reported by Haile-Mariam et al. (2004), using an earlier Australian data set, is similar to that observed in the current study ( -0.23 ; Table 6$)$, suggesting that cows with wider muzzles are likely to be less fertile.

\section{Relationship of Predicted LWT with Health (Survival and Fat-to-Protein Ratio)}

One of the hypotheses of this study was that smaller cows with limited capacity to consume adequate feed could experience negative energy balance or would 
have an increased chance of culling compared with large-sized cows. Our estimated genetic correlation between survival and predicted LWT was close to zero, suggesting that bigger cows have a similar level of survival as smaller cows. This agrees with Short and Lawlor (1992) and Larroque and Ducrocq (2001), who reported that body size is not related to longevity, although the former study was based on data collected about 30 yr ago. In Spanish Holstein cattle, a close-tozero genetic correlation between predicted LWT and functional herd life was reported (Pérez-Cabal and Alenda, 2003). Tsuruta et al. (2004) also reported a near-zero or slightly negative correlation between body size composite (predict LWT) and productive life in US Holsteins. Our results, however, do not support the observation by Hansen et al. (1999) that cows with big stature or size have a shorter herd life. Sasaki (2013), after extensive review of the literature, concluded that the relationship between size and survival depends on several environmental and genetic circumstances. In the current data, the genetic correlation of predicted LWT (i.e., best type mode) with survival was close to zero in high-LWT cows $(-0.08 \pm 0.07)$ as well as lowLWT cows $(-0.12 \pm 0.07)$.

The relationship between predicted LWT and F/P in the current study, although not conclusive, suggests that heavier cows are less likely to have high $\mathrm{F} / \mathrm{P}$ than smaller cows. This is in agreement with a recent study that observed that heavier cows experienced less metabolic stress than lighter cows (Frigo et al., 2010). Furthermore, the correlation of direct survival EBV (0.16) and SCC EBV (0.07), calculated using national data, with EBV for predicted LWT from the best type model shows weak evidence for the fact that heavier cows are able to withstand culling and mastitis compared with lighter cows. The correlation between overall survival (direct plus indirect) EBV released by ADHIS and EBV for predicted LWT was higher (0.28). Thus, further research to ascertain the relationship between survival including disease incidence and LWT is warranted.

The near-zero genetic correlation of stature and chest width with survival in the current study compares well with those in the UK (Wall et al. 2007). As in the current study, Wall et al. (2007) also found that among type traits, body depth and angularity were unfavorably correlated with life span.

Several studies have suggested that $\mathrm{F} / \mathrm{P}$ can be used as indicator of energy balance (de Vries and Veerkamp, 2000; Miglior et al., 2013; Negussie et al., 2013) and the results in the current study support this hypothesis, because high $\mathrm{F} / \mathrm{P}$ were associated with low LWT, particularly based on the best type and best type plus BCS model, low fertility, low survival, and low BCS.

\section{General Discussion}

In agreement with most other studies, selection for milk yield will result in increased predicted LWT. We also found that large-sized cows were slightly less fertile. The reason for this could be that large-sized cows experience a larger extent of negative energy balance compared with smaller cows when feed resources are limited and this may lead to poorer fertility compared with smaller cows. However, in pasture-based production systems, where the available forage is adequate and capacity to eat forage could also be a limiting factor, this will most likely affect smaller cows with limited capacity to consume enough roughage, particularly early in lactation. This may be the reason for the higher $\mathrm{F} / \mathrm{P}$ of smaller cows rather than large cows. However, the role of several factors not necessarily related to nutritional status of cows may contribute to the genetic correlation between predicted LWT and fertility as well (Walsh et al., 2011).

Although the main reason for predicting LWT in this study was to improve the accuracy of EBV for LWT that can be incorporated into the APR, obtaining predicted LWT data for other Australian dairy breeds could lead to the development of an all-breed genetic evaluation where all dairy breeds can be compared on the same scale, taking their LWT into account (Grainger and Goddard, 2004). This is important because differences between cows in maintenance requirements are larger among breeds than within breed.

When selecting on an economic index that considers LWT, less of the feed consumed is used for maintenance relative to that used for production, so overall profitability should be better than when LWT is ignored (e.g., Harris et al., 2007). The effectively zero genetic correlation between survival and predicted LWT suggests that including LWT EBV in the economic index with a negative economic value is unlikely to have unfavorable consequences. However, the fact that inclusion of BCS and bone quality in the prediction of LWT and that $\mathrm{F} / \mathrm{P}$ of smaller cows was slightly higher than that of larger cows may mean that continuous selection on such an index could lead to gradual reduction in genetic levels for health. Possible deterioration in fertility as a result of gradual reduction in BCS due to selection for lower LWT and increased milk yield could also be expected. One approach to deal with this might be to derive measures of energy balance that can be combined into the economic index (Wall et al., 2008). A similar outcome could also be achieved by broadening the breeding objective to include health traits as has been practiced in Nordic countries (Philipsson and Lindhé, 2003). When health data are limited, indica- 
tors of energy balance such as $\mathrm{F} / \mathrm{P}$ and BCS could be used to improve the quality of energy balance (Miglior et al., 2013). In any case, it is worth monitoring the relationship between predicted LWT and health (Frigo et al., 2010) or indicators of energy balance.

\section{CONCLUSIONS}

The best prediction of LWT included the following type traits: stature, chest width, bone quality, udder depth, central ligament, and muzzle width; this explained $40 \%$ of the variation in raw LWT. An even better prediction of LWT is using visual assessments by professional type classifiers, which explained around $60 \%$ of the variation in LWT. However, for calculating EBV for bulls, both predicted LWT from type traits or visually assessed LWT were equally accurate. The predicted measures of LWT were positively genetically correlated with ECM yield and had near-zero correlation with survival. The correlations of different measures of LWT with fertility traits suggest that selection for reduced LWT may not cause deterioration in fertility traits. Based on the results from this study, the inclusion of predicted LWT with negative economic values into the breeding objective will have no effect on fitness traits.

\section{ACKNOWLEDGMENTS}

Liveweight data were provided by the Holstein Association of Australia (Hawthorn BC, VIC, Australia). We thank Rohan Butler (Holstein Association of Australia) for coordinating the data collection. The rest of the data were extracted from the Australian Dairy Herd Improvement Scheme database. We thank Kevin Beard and Paul Koh (ADHIS, Melbourne, Australia) for their help with extraction of the different data sets used in this study.

\section{REFERENCES}

ADHIS (Australian Dairy Herd Improvement Scheme). 2004. ABV Handbook Cows N Genes Workshop Manual, Melbourne, Australia.

Banos, G., and M. P. Coffey. 2012. Technical note: Prediction of liveweight from linear conformation traits in dairy cattle. J. Dairy Sci. 95:2170-2175.

Becker, J. C., B. J. Heins, and L. B. Hansen. 2012. Costs for health care of Holstein cows selected for large versus small body size. J. Dairy Sci. 95:5384-5392.

Bell, M. J., R. J. Eckard, M. Haile-Mariam, and J. E. Pryce. 2013. The effect of changing cow production and fitness traits on net income and greenhouse gas emissions from Australian dairy systems. J. Dairy Sci. 96:7918-7931.

Berry, D. P., F. Buckley, P. Dillon, R. D. Evans, M. Rath, and R. F. Veerkamp. 2003. Genetic relationships among body condition score, body weight, milk yield and fertility in dairy cows. J. Dairy Sci. $86: 2193-2204$.
Coffey, M. P., G. Simm, W. G. Hill, and S. Brotherstone. 2003. Genetic evaluations of dairy bulls for daughter energy balance profiles using linear type scores and body condition score analyzed using random regression. J. Dairy Sci. 86:2205-2212.

Collard, B. L., P. J. Boettcher, J. C. M. Dekkers, D. Petitclerc, and L. R. Schaeffer. 2000. Relationships between energy balance and health traits of dairy cattle in early lactation. J. Dairy Sci. 83:2683-2690.

de Haas, Y., J. J. Windig, M. P. L. Calus, J. Dijkstra, M. de Haan, A. Bannink, and R. F. Veerkamp. 2011. Genetic parameters for predicted methane production and potential for reducing enteric emissions through genomic selection. J. Dairy Sci. 94:6122-6134.

de Vries, M. J., and R. F. Veerkamp. 2000. Energy balance of dairy cattle in relation to milk production variables and fertility. J Dairy Sci. 83:62-69.

Earle, D. F. 1979. A guide to scoring dairy cow condition. J. Agric (Victoria) 74:228-231.

Frigo, E., C. D. Dechow, O. Pedron, and B. G. Cassell. 2010. The genetic relationship of body weight and early-lactation health disorders in two experimental herds. J. Dairy Sci. 93:1184-1192.

Gilmour, A. R., B. J. Gogel, B. R. Cullis, and R. Thompson. 2009. ASReml User Guide. Release 3.0. VSN International Ltd., Hemel Hempstead, UK.

Grainger, C., and M. E. Goddard. 2004. A review of the effects of dairy breed on feed conversion efficiency-An opportunity lost? Anim. Prod. Austral. 25:77-80.

Haile-Mariam, M., P. J. Bowman, and M. E. Goddard. 2004. Genetic parameters of fertility traits and their genetic correlation with production, type, workability, live weight, survival index and somatic cell count. Aust. J. Agric. Res. 55:77-87.

Haile-Mariam, M., R. Butler, and J. E. Pryce. 2013. Genetics of body condition score and its relationship with fertility, milk and survival in Holstein cows in Australia. Proc. Assoc. Advmt. Anim. Breed. Genet. 20:315-318.

Hansen, L. B., J. B. Cole, G. D. Marx, and A. J. Seykora. 1999. Productive life and reasons for disposal of Holstein cows selected for large versus small body size. J. Dairy Sci. 82:795-801.

Harris, B., J. E. Pryce, and W. A. Montgomerie. 2007. Experiences from breeding for economic efficiency in dairy cattle in New Zealand. Proc. Assoc. Advmt. Anim. Breed. Genet. 17:434-444.

Hazel, L. N. 1943. The genetic basis for constructing selection indices. Genetics 28:476-490.

Hoffman, P. C., N. M. Brehm, S. G. Price, and A. Prill-Adams. 1996. Effect of accelerated postpubertal growth and early calving on lactation performance of primiparous Holstein heifers. J. Dairy Sci. 79:2024-2031.

Larroque, H., and V. Ducrocq. 2001. Relationship between type and longevity in the Holstein breed. Genet. Sel. Evol. 33:39-59.

Madgwick, P., K. Beard, and M. E. Goddard. 1991. Possibilities for incorporating selection for feed conversion efficiency into the national dairy herd improvement program. Proc. Assoc. Advmt. Anim. Breed. Genet. 9:45-48.

Miglior, F., A. Koeck, J. Jamrozik, D. F. Kelton, S. Loker, K. Stachowicz, and F. S. Schenkel. 2013. Genetic evaluation for resistance to metabolic diseases in Canadian Holsteins. Proc. Assoc. Advmt. Anim. Breed. Gen. 20:199-202.

Montgomerie, B. 2007. Experience with data recording and genetic evaluation of live weight for dairy cows in New Zealand. Interbull Bull. 36:37-40.

Negussie, E., I. Strandén, and E. A. Mäntysaari. 2013. Genetic associations of test-day fat:protein ratio with milk yield, fertility, and udder health traits in Nordic Red cattle. J. Dairy Sci. 96:1237-1250.

Pérez-Cabal, M. A., and R. Alenda. 2003. Lifetime profit as an individual trait and prediction of its breeding values in Spanish Holstein cows. J. Dairy Sci. 86:4115-4122.

Pérez-Cabal, M. A., R. González Santillana, and R. Alenda. 2006. Mature body weight and profit selection in Spanish dairy cattle. Livest. Sci. 99:257-266.

Philipsson, J., and B. Lindhé. 2003. Experiences of including reproduction and health traits in Scandinavian dairy cattle breeding programmes. Livest. Prod. Sci. 83:99-112. 
Pryce, J. E., and B. L. Harris. 2006. Genetics of body condition score in New Zealand dairy cows. J. Dairy Sci. 89:4424-4432.

Robertson, A., and J. M. Rendel. 1950. The use of progeny testing with artificial insemination in dairy cattle. J. Genet. 50:21-31.

Sasaki, O. 2013. Estimation of genetic parameters for longevity traits in dairy cattle: A review with focus on the characteristics of analytical models. Anim. Sci. J. 84:449-460.

Short, T. H., and T. J. Lawlor. 1992. Genetic parameters of conformation traits, milk yield, and herd life in Holsteins. J. Dairy Sci. 75:1987-1998.

Sjaunja, L. O., L. Baevre, L. Junkkarinen, J. Pedersen, and J. Setälä. 1991. A Nordic proposal for an energy corrected milk (ECM) formula. Pages 156-157 in Performance Recording of Animals: State of the Art, 1990. P. Gaillon and Y. Chabert, ed. EAAP Publication no. 50. Pudoc, Wageningen, the Netherlands.

Tsuruta, S., I. Misztal, and T. J. Lawlor. 2004. Genetic correlations among production, body size, udder, and productive life traits over time in Holsteins. J. Dairy Sci. 87:1457-1468.

Valentine, H., L. Jones, K. T. Beard, and R. Poole. 2000. The development of the Australian profit ranking for genetic selection of Australian dairy cattle. Australian Dairy Herd Improvement Scheme (ADHIS), Melbourne, Australia.

Vallimont, J. E., C. D. Dechow, J. M. Daubert, M. W. Dekleva, J. W. Blum, C. M. Barlieb, W. Liu, G. A. Varga, A. J. Heinrichs, and C. R. Baumrucker. 2010. Genetic parameters of feed intake, production, body weight, body condition score, and selected type traits of Holstein cows in commercial tie-stall barns. J. Dairy Sci. 93:4892-4901.

VanRaden, P. M. 2004. Invited review: Selection on net merit to improve lifetime profit. J. Dairy Sci. 87:3125-3131.

Veerkamp, R. F. 1998. Selection for economic efficiency of dairy cattle using information on live weight and feed intake: A review . J. Dairy Sci. 81:1109-1119.

Veerkamp, R. F., and S. Brotherstone. 1997. Genetic correlations between linear type traits, food intake, live weight and condition score in Holstein Friesian dairy cattle . Anim. Sci. 64:385-392.

Visscher, P. M., P. J. Bowman, and M. E. Goddard. 1994. Breeding objectives for pasture based dairy production systems. Livest. Prod. Sci. 40:123-137.

Wall, E., M. P. Coffey, and P. R. Amer. 2008. A theoretical framework for deriving direct economic values for body tissue mobilization traits in dairy cattle. J. Dairy Sci. 91:343-353.

Wall, E., M. P. Coffey, and S. Brotherstone. 2007. The relationship between body energy traits and production and fitness traits in first-lactation Dairy cows. J. Dairy Sci. 90:1527-1537.

Walsh, S. W., E. J. Williams, and A. C. O. Evans. 2011. A review of the causes of poor fertility in high milk producing dairy cows. Anim. Reprod. Sci. 123:127-138. 